\title{
Importance of low substrate arsenic content in mushroom cultivation and safety of final food product
}

\author{
M. Mleczek ${ }^{1}$ P. Niedzielski ${ }^{2}$ M. Siwulski ${ }^{3} \cdot$ P. Rzymski $^{4} \cdot$ M. Gąsecka ${ }^{1}$ P. Goliński ${ }^{1}$ • \\ L. Kozak ${ }^{2,5}$ - T. Kozubik ${ }^{1}$
}

Received: 2 July 2015 / Revised: 24 August 2015 / Accepted: 30 August 2015 / Published online: 9 September 2015

(C) The Author(s) 2015. This article is published with open access at Springerlink.com

\begin{abstract}
Mushrooms are known to accumulate various concentrations of different arsenic (As) species depending on the metalloid residue level in the substrate. These species are of different toxicity to humans and may represent a significant health problem. In the present study, edible fungal species (Agaricus bisporus, Pleurotus ostreatus, Pleurotus eryngii and Hericium erinaceus) grown separately on substrate containing different As species (As(III), $\mathrm{As}(\mathrm{V})$ and dimethylarsinic acid-DMA; each form individually) at different concentrations $(0.1-0.8 \mathrm{mM})$ exhibited different accumulation of total As, the lowest being in A. bisporus $\left(1.97 \pm 0.14 \mathrm{mg} \mathrm{kg}^{-1} \mathrm{DW}\right)$ and the highest in P. ostreatus HK35 (68.8 $\left.\pm 19.0 \mathrm{mg} \mathrm{kg}^{-1} \mathrm{DW}\right)$ and P. eryngii $\left(68.0 \pm 31.0 \mathrm{mg} \mathrm{kg}^{-1} \mathrm{DW}\right)$. The highest biomass was observed for A. bisporus, regardless of the As forms and their concentration (from $341.24 \pm 13.16$ to $378.49 \pm 14.57 \mathrm{~g}$ ). This confirms that $A$. bisporus is highly resistant to As due to low metalloid uptake and accumulation. To ensure quality of cultivated mushroom species and safety of final food product to human health, there is
\end{abstract}

M. Mleczek

mirekmm@up.poznan.pl

1 Department of Chemistry, Poznan University of Life Sciences, Poznań, Poland

2 Faculty of Chemistry, Adam Mickiewicz University in Poznań, Poznań, Poland

3 Department of Vegetable Crops, Poznan University of Life Sciences, Poznań, Poland

4 Laboratory of Environmental Research, Poznan University of Medical Sciences, Poznań, Poland

5 Department of Food, Nutrition and Food Contact Materials, Poviat Sanitary and Epidemiological Station, Poznań, Poland a necessity to control the level of substrate contamination with As.

Keywords Accumulation - Arsenic $\cdot$ Cultivated edible mushroom $\cdot$ Speciation analysis

\section{Introduction}

Environmental arsenic (As) occurs in various forms, including inorganic_-arsenate As(V) and arsenite As(III)and organic (the effect of methylation of inorganic species in soil) [1], that exhibit different toxicity. In general, $\mathrm{As}(\mathrm{III})$ and $\mathrm{As}(\mathrm{V})$ are considered as a serious health threat, magnified by their high bioavailability in the human gastrointestinal tract and potential to accumulate in the liver, kidneys, lungs and skin. Methylated forms such as monomethylarsonic acid $\left(\mathrm{MMA}-\mathrm{CH}_{5} \mathrm{AsO}_{3}\right)$, dimethylarsinic acid $\left(\mathrm{DMA}-\mathrm{C}_{2} \mathrm{H}_{7} \mathrm{AsO}_{2}\right)$, tetramethylarsonium ion (TETRA- $\left.\left(\mathrm{CH}_{3}\right)_{4} \mathrm{As}^{+}\right)$and trimethylarsine oxide (TMAO- $\left.\left(\mathrm{CH}_{3}\right)_{3} \mathrm{AsO}\right)$ are known to be only moderately toxic, while others, such as arsenosugars (glycerol, phosphate, sulphonate and sulphate sugar), arsenocholine $\left(\mathrm{AC}-\left(\mathrm{CH}_{3}\right)_{3} \mathrm{As}^{+} \mathrm{CH}_{2} \mathrm{CH}_{2} \mathrm{OH}\right)$ and arsenobetaine $(\mathrm{AB}-$ $\left.\left(\mathrm{CH}_{3}\right)_{3} \mathrm{As}^{+} \mathrm{CH}_{2} \mathrm{COO}^{-}\right)$, are considered as safe. Nevertheless, As can induce various adverse effects at the molecular, biochemical and clinical levels, whereas mechanisms enabling As metabolism are extremely rare in the human population [2]. From an epidemiological perspective, As exposures increase the risk of bladder and skin cancer, cardiovascular diseases, diabetes mellitus and impaired reproduction.

The U.S. Food and Drug Administration (FDA) and other important bodies regulating food safety recognize the need to keep the As intake at the lowest possible level and 
to control it through legislation. The provisional tolerable weekly intake (PTWI) of total As by the Joint FAO/WHO Expert Committee on Food Additives was set at $15 \mu \mathrm{g} \mathrm{kg}^{-1}$ body weight [3] but later withdrawn because the lower limit on the benchmark dose for a $0.5 \%$ increased incidence of lung cancer was in the similar range [4]. The minimal risk level (MRL) for orally ingested inorganic As proposed by the Agency for Toxic Substances and Disease Registry was established at the level of $0.005 \mathrm{mg} \mathrm{kg}^{-1}$ day $^{-1}$ and was based on a lowest observed adverse effect level (LOAEL) of $0.05 \mathrm{mg}_{\mathrm{As}} \mathrm{kg}^{-1} \mathrm{day}^{-1}$ for gastrointestinal effects [5]. Chronic daily intakes of at least $600 \mu \mathrm{g}$ of inorganic As have been associated with adverse health effects, but detrimental action of lower doses cannot be ruled out [6]. Therefore, content of inorganic As forms rather than total concentration of this metalloid in food products needs to be routinely monitored. Over the years, numerous studies have estimated contribution of various food products in dietary intake of inorganic As and indicated that some may represent a significant source of dietary exposure at levels close to the toxicological limits [7-11]. Nevertheless, its level in edible mushrooms is not regulated by law and only occasionally subjected to study [12].

Mushrooms are known to effectively accumulate various trace elements (metals and metalloids such as Se or As), a phenomenon that occurs in their fruiting bodies at levels that may significantly exceed those found in aboveground parts of plants or animal tissues [13-16]. On the other hand, the total As content $\left(\mathrm{As}_{\text {total }}\right)$ in the fruiting bodies can greatly vary from concentrations below $0.05 \mathrm{mg} \mathrm{kg}^{-1} \mathrm{DW}$ [17] up to $1420 \mathrm{mg} \mathrm{kg}^{-1} \mathrm{DW}$ [18] and is likely determined by species-specific biological features and the level of environmental or substrate contamination $[19,20]$.

It is crucial for food and health safety that the substrates used for mushroom cultivation have the lowest possible content of toxic elements, including As. Various materials have been investigated for this purpose and include casing soil, horse and chicken manure, shredded wheat straw as well as rice and corn flour. Some of these materials have already been found to contain significant amounts of $\mathrm{As}_{\text {total }}$ [21-24]. Because As toxicity is highly species dependent (although mushrooms were suggested to potentially biotransform inorganic As into the organic form as a mechanism of ecological tolerance), the analyses of $\mathrm{As}_{\text {total }}$ content in both substrate and fruiting bodies might not fully reflect the actual health hazards. It is only through speciation analyses that the risk assessment can be achieved.

Our previous study showed that the wild edible mushroom species Xerocomus badius growing at polluted sites can accumulate significant levels of $\mathrm{As}(\mathrm{III}), \mathrm{As}(\mathrm{V})$ and DMA up to a level of 27,40 and $88 \mathrm{mg} \mathrm{kg}^{-1}$, respectively. In our opinion, the quality of substrate is fundamental for As content and toxicity in wild and cultivated mushrooms
[25]. Here, we present data on accumulation of As species in the fruiting bodies of the four most popular cultivated edible mushroom species in Central Europe (Agaricus bisporus, Pleurotus ostreatus, Pleurotus eryngii and Hericium erinaceus) in relation to As level in growth substrate.

\section{Materials and methods}

\section{Experimental design}

\section{Agaricus bisporus}

The compost for the experiment was collected from commercial production of Agaricus bisporus. It was composed of wheat straw, chicken manure and gypsum $(1000,900$ and $85 \mathrm{~kg}$, respectively) using a conventional method characteristic for phase II (fermentation and pasteurization). The compost was then mixed with all three arsenic solutionssodium (meta)arsenite $\left(\mathrm{AsNaO}_{2}\right)$, sodium arsenate dibasic heptahydrate $\left(\mathrm{Na}_{2} \mathrm{HAsO}_{4} \cdot 7 \mathrm{H}_{2} \mathrm{O}\right)$ and dimethylarsinic acid $\left(\left(\mathrm{CH}_{3}\right)_{2} \mathrm{As}(\mathrm{O}) \mathrm{OH}\right)$ - to a final concentration of each form: $0.1,0.2,0.4,0.6$ and $0.8 \mathrm{mM}$. The substrate was then mixed with mycelium (Sylvan A15 strain) using a POLYMIX PX-SR 90 D stirrer (KINEMATICA AG, Littau-Luzern, Switzerland) in the amount of $5 \%$ of the substrate mass and placed in plastic containers $(13 \times 25 \times 35 \mathrm{~cm})$. Each of them contained $3 \mathrm{~kg}$ of the substrate. Incubation was carried out at $25^{\circ} \mathrm{C}$ and $90-95 \%$ moisture content until the substrate became completely covered by mycelium. Then, the substrate was covered with a 5-cm layer of casing soil (prepared from Sphagnum sp. peat and chalk in the ratio of 5:1 by volume) with $70 \%$ moisture content and incubated again at the above-mentioned conditions. Once the casing soil became totally overgrown by mycelium, the temperature was decreased to $16{ }^{\circ} \mathrm{C}$. The cultivation was watered to maintain constant moisture and aerated to keep the $\mathrm{CO}_{2}$ concentration below $1000 \mathrm{ppm}$. The fruiting bodies of the first flush were harvested for further analyses. The yield was expressed as total weight of whole fruiting bodies.

\section{Pleurotus ostreatus}

The substrate for P. ostreatus HK35 and H195 was prepared from wheat straw cut into chaff $4-5 \mathrm{~cm}$ long. The straw for the experiment was moistened to $60 \%$ and pasteurized at $60^{\circ} \mathrm{C}$ for $24 \mathrm{~h}$. The As was added using the same solutions and at the same mM concentrations as already described in the previous subsection. The substrate was then mixed with grain mycelium (on wheat kernels) which constituted $3 \%$ in relation to the wet weight of the substrate and placed in bags of perforated foil. Each bag contained $1 \mathrm{~kg}$ of the substrate. Mycelium was incubated at $25^{\circ} \mathrm{C}$ and $85-90 \%$ 
air relative humidity. When the substrate was totally covered with the mycelium, it was transferred to the cultivation chamber with the temperature $15-16{ }^{\circ} \mathrm{C}$, air relative humidity of $85-90 \%$ and under $500 \mathrm{~lx}$ irradiance using fluorescent light with the photoperiod 10-h light and 14-h dark. The $\mathrm{CO}_{2}$ concentration level was maintained below $1000 \mathrm{ppm}$ by controlled aeration. Carpophores were harvested as they matured. Yield included carpophores with stipe.

\section{Pleurotus eryngii and Hericium erinaceus}

The substrate for $P$. eryngii and $H$. erinaceus was prepared from a mixture of beech sawdust and flax shives (3:1 vol) which was additionally supplemented with $20 \%$ wheat bran, $5 \%$ corn flour and $1 \%$ gypsum. The mixture was moisturized with distilled water to the water content of $45 \%$. The substrate prepared as for P. ostreatus was placed in polypropylene bags and sterilized at $121{ }^{\circ} \mathrm{C}$ for $1 \mathrm{~h}$ and cooled to $25^{\circ} \mathrm{C}$. The As salts were added using the same solutions at the same $\mathrm{mM}$ concentrations as already described in the two previous subsections. The substrates were then mixed with grain spawn (on wheat grain) of the examined mushroom species ( $5 \%$ of substrate weight) and placed in 1-L polypropylene bottles. Each bottle was filled with $350 \mathrm{~g}$ of the substrate, closed with a filter cover and incubated at $25{ }^{\circ} \mathrm{C}$ and air relative humidity of $80-85 \%$ until the substrate was totally overgrown with mycelium. Next, the bottles with removed covers and sacks with the top part of the foil cut-off were placed in the cultivation chamber, for fructification, under air relative humidity $85-90 \%$ and temperature $14 \pm 1{ }^{\circ} \mathrm{C}$ for $P$. eryngii and $16 \pm 1{ }^{\circ} \mathrm{C}$ for $\mathrm{H}$. erinaceus. Irradiance of $500 \mathrm{~lx}$ fluorescent light with a photoperiod regime of 12-h light and 12-h dark was applied. Carpophores were harvested as they matured. Yield was expressed as total weight of whole fruiting bodies.

\section{Extraction procedure}

After harvesting, all samples of substrates, fruiting bodies and carpophores were dried at $40{ }^{\circ} \mathrm{C}$ to constant weight. The extraction procedure was based on the work of Gonzálvez et al. [26], modified to conditions needed for hyphenated system As species determination. One gram of the mushroom sample (homogenized by rubbing and sieving through a $0.02 \mathrm{~mm}$ sieve) in a glass flask containing $10 \mathrm{~mL}$ of phosphoric acid and several drops of Triton was extracted in an ultrasonic bath $(30 \mathrm{~min}$ at ambient temperature). Next the solution was filtered with filter paper (washed with $200 \mathrm{~mL}$ of water and $20 \mathrm{~mL}$ of phosphoric buffer) or centrifuged. The $\mathrm{pH}$ of the solution was adjusted to $6.0-6.5$ by addition of $10 \mathrm{~mol} \mathrm{~L}^{-1} \mathrm{NaOH}$, and finally, the solution was diluted to $20 \mathrm{~mL}$ with phosphate buffer. The As species in the acid extracts were determined by HPLC-HG-AAS immediately after the extraction procedure. The determination limits were $0.04 \mathrm{mg} \mathrm{kg}^{-1}$ for each studied form of As. All analyses were performed in parallel using two analytical systems, and the mean value of As(III), As(V) and DMAA was given as the final result. Importantly, in this method hydrides were formed only by reduction of $\mathrm{As}(\mathrm{III}), \mathrm{As}(\mathrm{V})$ and DMAA [27] and no other As-organic compound [28]. At high $\mathrm{HCl}$ concentration, reduction of methyl derivatives of As practically does not take place.

\section{Instrumentation}

Construction and optimization of the HPLC-HG-AAS system was described in our previous paper [24]. Two independent hyphenated analytical systems were used simultaneously in the single element mode for As determination. First, a liquid chromatograph (LC-10A) equipped with a pump (LC-10AT), a vacuum degasser unit (GT-104) and a thermostat by a column oven (CTO-10ASvp) (Shimadzu, Japan), anion-exchange column (Supelco, USA) LC-SAX1 (250 mm, $4.6 \mathrm{~mm}$ i.d.). The chromatographic run was isocratic at $3 \mathrm{~mL} \mathrm{~min}^{-1}$ of phosphate buffer (50 mmol L ${ }^{-1} \mathrm{Na}_{2} \mathrm{HPO}_{4}$ and $5 \mathrm{mmol} \mathrm{L}{ }^{-1} \mathrm{KH}_{2} \mathrm{PO}_{4} 2 \mathrm{H}_{2} \mathrm{O}$ ) with an injection volume of $200 \mu \mathrm{L}$. PEEK (polyetheretherketone) tubing was inserted into a Tygon sleeve for transfer of the eluent from the LC column to the hydride generation unit. The continuous hydride generation system (VGA-77, Varian, Australia) consisted of a manually controlled peristaltic pump with Tygon tubing ( $0.6 \mathrm{~mm}$ i.d.), one reaction coil (polytetrafluoroethylene (PTFE) tubing $0.8 \mathrm{~mm}$ i.d., $75 \mathrm{~cm}$ length) and three-way connectors. The gas-liquid separator was made of glass, and the interior dead volume was about $3 \mathrm{~mL}$. The detector was the spectrometer model SpectrAA 220FS (Varian, Australia), with atomization of As hydrides (detected at $193.7 \mathrm{~nm}$ ) in a quartz tube heated electrothermally to $900{ }^{\circ} \mathrm{C}$ (ETC.-60, Varian, Australia). The second analytical system consisted of the HPLC pump ProStar 240 Ternary Solvent Delivery Module (Varian, Australia), the Rheodyne PEEK (IDEX, USA) chromatographic valve with $200-\mu$ L PEEK loop, the Zorbax SAX (250 mm length, $4.6 \mathrm{~mm}$ i.d.) HPLC column (Agilent, USA) and the atomic absorption spectrometer SpectrAA 280FS (Agilent, USA) as a chromatographic detector. The HPLC-AAS connection was achieved via the hydride generation unit VGA-77 and ETC.-60 quartz atomizer detailed above (Agilent, USA) using PEEK tubing identically as for the first analytical system. The chromatographic run was isocratic at $2.5 \mathrm{~mL} \mathrm{~min}{ }^{-1}$ of phosphate buffer $\left(100 \mathrm{mmol} \mathrm{L}^{-1} \mathrm{Na}_{2} \mathrm{HPO}_{4}\right.$ and $10 \mathrm{mmol} \mathrm{L}^{-1}$ $\mathrm{KH}_{2} \mathrm{PO}_{4} 2 \mathrm{H}_{2} \mathrm{O}$ ). 


\section{Gases and reagents}

Compressed argon gas (Linde, Poland) was employed as the carrier gas for As vapour for the quartz cell without further purification. Water was redistilled and purified with a Milli-Q water purification system (Millipore, USA). Standard solutions (1000 $\mathrm{mg} \mathrm{L}^{-1}$ of As) of As(III), As(V) and DMAA were prepared by dissolving the $\mathrm{NaAsO}_{2}$, $\mathrm{Na}_{2} \mathrm{HAsO}_{4} \quad 7 \mathrm{H}_{2} \mathrm{O}$ and DMAA, respectively (SigmaAldrich, USA). The standard stock solutions were stored in polyethylene bottles at $4{ }^{\circ} \mathrm{C}$ in the dark. Low-concentration standards prepared by dilution of the stock solutions were prepared daily. Sodium tetrahydroborate, used as reducing solution, was prepared daily by dissolving $\mathrm{NaBH}_{4}$ (Merck, Darmstadt, Germany) in high-purity water and stabilizing with $1 \%$ (w/w) $\mathrm{NaOH}$ (Merck, Darmstadt, Germany) to decrease the decomposition rate and was used without filtration. The $\mathrm{HCl}$ solution used in the procedures was of the highest quality (suprapure) grade (Merck, Darmstadt, Germany). The buffer and buffered mobile phase were prepared by mixing disodium hydrophosphate $\left(\mathrm{Na}_{2} \mathrm{HPO}_{4}\right)$ and potassium dihydrophosphate $\left(\mathrm{KH}_{2} \mathrm{PO}_{4} \quad 2 \mathrm{H}_{2} \mathrm{O}\right)$, obtained from Merck. The phosphoric acid and Triton (both analytical grade) were purchased from Merck (Darmstadt, Germany).

\section{Statistical analysis}

All analyses were prepared in triplicate, and the results were expressed as mean value $\pm \mathrm{SD}$. The data were processed using Microsoft Excel 2010. Statistical analysis was done using STATISTICA 10 with ANOVA and post hoc Tukey's test (the results marked with identical letters in columns show no differences at the significance level $\alpha<0.05$ ).

\section{Results}

\section{Accumulation of As species in collected fruiting bodies}

The studied mushroom species were able to grow on substrates supplemented with every As concentration except $P$. ostreatus HK35, growth of which entirely ceased at $>0.2 \mathrm{mM}$. All As species except DMAA were detected in their fruiting bodies (Table 1). The total As content in mushrooms did not necessarily follow the As concentrations added to growth substrate. The highest levels were observed after addition of $0.2 \mathrm{mM}$ in A. bisporus $\left(2.7 \pm 0.2 \mathrm{mg} \mathrm{kg}^{-1}\right.$ DW), P. ostreatus $\mathrm{H} 195\left(32.7 \pm 4.3 \mathrm{mg} \mathrm{kg}^{-1} \mathrm{DW}\right)$ and $P$. ostreatus HK35 $\left(68.8^{\mathrm{a}} \pm 19.0 \mathrm{mg} \mathrm{kg}{ }^{-1} \mathrm{DW}\right), 0.4 \mathrm{mM}$ in H. erinaceus $\left(13.7 \pm 5.4 \mathrm{mg} \mathrm{kg}^{-1} \mathrm{DW}\right)$ and $0.6 \mathrm{mM}$ in $P$. eryngii $\left(68.0 \pm 31.0 \mathrm{mg} \mathrm{kg}^{-1} \mathrm{DW}\right)$.
Interspecific differences in the uptake and accumulation of studied As species were observed. In general, the lowest levels of $\mathrm{As}(\mathrm{III})$ and $\mathrm{As}(\mathrm{V})$ and organic As were found for A. bisporus, despite the initial As content in the substrate. On the other hand, accumulation of inorganic As (especially As(III)) was the highest in P. ostreatus $\mathrm{H} 195$ and $P$. ostreatus HK35. The increase in inorganic As in the fruiting bodies of the studied mushrooms did not necessarily follow the simultaneous increase in the organic As content (Table 1).

\section{Changes in mushroom biomass}

Regardless of As concentration, the highest biomass was found for A. bisporus fruiting bodies (Table 2). Moreover, it did not differ between groups exposed to various As content in substrate.

The lowest observed biomass of A. bisporus was still higher than that of any other studied mushroom species, including their controls. Two other species, $H$. erinaceus and $P$. eryngii, treated with the highest assayed As level $(0.8 \mathrm{mM})$ produced fruiting bodies of biomass reduced only by 12.3 and $4.9 \%$, respectively. In contrast, $P$. ostreatus $\mathrm{H} 195$ and P. ostreatus HK35 were found to be the most susceptible to As presence. Compared to the control, over a fourfold decrease in biomass was observed for the former species treated with $0.8 \mathrm{mM}$ of As, whereas the latter did not grow at As concentrations higher than $0.2 \mathrm{mM}$. No clear linear dose-dependent response was observed for any mushroom species (Figs. 1a, b, 2, 3, 4).

\section{Discussion}

There is no doubt that mushrooms cultivated for human consumption should not introduce a health risk associated with As exposures. Therefore, numerous studies have addressed the bioaccumulation of As in different edible species. It was also suggested that at least some species may perform biotransformation of As into arsenobetaine, an organic form of lower toxicity. However, metabolic routes of this process and whether the initial As content in the growth substrate has any impact on it remain unclear. The present study demonstrates that commercially cultivated mushroom species may significantly vary in As uptake and that those species which accumulate lower inorganic As levels produce greater biomass.

The low level of As accumulation and high resistance of A. bisporus were previously indicated in the study by Soeroes et al. [29] in which the mushrooms were grown with the addition of $1000 \mathrm{mg} \mathrm{kg}^{-1}$ of $\mathrm{As}(\mathrm{V})$. Surprisingly, the concentration of arsenobetaine was half the content found in the control, and the accumulation of As occurred mainly in the form of MMA 
Table 1 Effect of the different As species concentration $(\mathrm{mM})$ in the substrate on its content in the mushroom $\left(\mathrm{mg} \mathrm{kg}^{-1} \mathrm{DW}\right)$

\begin{tabular}{|c|c|c|c|c|c|c|}
\hline As species addition & $\mathrm{As}(\mathrm{III})$ & $\operatorname{As}(\mathrm{V})$ & DMAA & $\mathrm{As}_{\text {inorg }}$ & $\mathrm{As}_{\text {org }}$ & $\mathrm{As}_{\text {total }}$ \\
\hline \multicolumn{7}{|l|}{ A. bisporus } \\
\hline Control & $0.26^{\mathrm{a}} \pm 0.20$ & $0.22^{c} \pm 0.26$ & \multirow[t]{6}{*}{$<0.10$} & $0.48^{\mathrm{c}} \pm 0.25$ & $1.50^{\mathrm{a}} \pm 0.46$ & $1.97^{\mathrm{bc}} \pm 0.14$ \\
\hline 0.1 & $0.28^{\mathrm{a}} \pm 0.06$ & $0.76^{\mathrm{bc}} \pm 0.07$ & & $1.04^{\mathrm{bc}} \pm 0.12$ & $0.87^{\mathrm{ab}} \pm 0.85$ & $1.91^{\mathrm{bc}} \pm 0.94$ \\
\hline 0.2 & $0.46^{\mathrm{a}} \pm 0.07$ & $1.65^{\mathrm{a}} \pm 0.19$ & & $2.11^{\mathrm{a}} \pm 0.19$ & $0.62^{\mathrm{ab}} \pm 0.09$ & $2.73^{\mathrm{a}} \pm 0.24$ \\
\hline 0.4 & $0.39^{\mathrm{a}} \pm 0.08$ & $1.38^{\mathrm{ab}} \pm 0.37$ & & $1.77^{\mathrm{ab}} \pm 0.30$ & $0.19^{b} \pm 0.03$ & $1.95^{\mathrm{bc}} \pm 0.33$ \\
\hline 0.6 & $0.33^{\mathrm{a}} \pm 0.24$ & $1.05^{\mathrm{ab}} \pm 0.26$ & & $1.37^{\mathrm{abc}} \pm 0.50$ & $0.67^{\mathrm{ab}} \pm 0.19$ & $2.04^{\mathrm{b}} \pm 0.41$ \\
\hline 0.8 & $0.30^{\mathrm{a}} \pm 0.06$ & $1.01^{\mathrm{ab}} \pm 0.14$ & & $1.31^{\mathrm{abc}} \pm 0.19$ & $0.11^{\mathrm{b}} \pm 0.05$ & $1.41^{\mathrm{c}} \pm 0.20$ \\
\hline \multicolumn{7}{|l|}{ H. erinaceus } \\
\hline Control & $0.21^{b} \pm 0.08$ & $0.14^{\mathrm{b}} \pm 0.03$ & \multirow[t]{6}{*}{$<0.10$} & $0.35^{\mathrm{c}} \pm 0.11$ & $1.21^{\mathrm{b}} \pm 0.16$ & $1.56^{\mathrm{b}} \pm 0.21$ \\
\hline 0.1 & $0.42^{b} \pm 0.07$ & $0.83^{\mathrm{ab}} \pm 0.30$ & & $1.25^{\mathrm{abc}} \pm 0.30$ & $0.19^{b} \pm 0.07$ & $1.44^{\mathrm{b}} \pm 0.34$ \\
\hline 0.2 & $0.25^{\mathrm{b}} \pm 0.02$ & $0.82^{\mathrm{ab}} \pm 0.13$ & & $1.07^{\mathrm{bc}} \pm 0.11$ & $0.63^{b} \pm 0.08$ & $1.69^{\mathrm{b}} \pm 0.18$ \\
\hline 0.4 & $3.99^{\mathrm{a}} \pm 2.66$ & $3.05^{\mathrm{a}} \pm 2.31$ & & $7.04^{\mathrm{a}} \pm 4.92$ & $6.69^{\mathrm{a}} \pm 3.54$ & $13.73^{\mathrm{a}} \pm 5.41$ \\
\hline 0.6 & $2.19^{\mathrm{ab}} \pm 0.49$ & $2.45^{\mathrm{ab}} \pm 0.31$ & & $4.64^{\mathrm{abc}} \pm 0.48$ & $6.70^{\mathrm{a}} \pm 1.05$ & $11.34^{\mathrm{a}} \pm 1.52$ \\
\hline 0.8 & $3.11^{\mathrm{ab}} \pm 1.46$ & $3.12^{\mathrm{a}} \pm 0.44$ & & $6.24^{\mathrm{ab}} \pm 1.70$ & $1.86^{\mathrm{b}} \pm 0.72$ & $8.10^{\mathrm{b}} \pm 1.97$ \\
\hline \multicolumn{7}{|l|}{ P. eryngii } \\
\hline Control & $0.23^{b} \pm 0.19$ & $0.19^{b} \pm 0.25$ & \multirow[t]{6}{*}{$<0.10$} & $0.43^{b} \pm 0.40$ & $1.28^{c} \pm 0.51$ & $1.71^{\mathrm{b}} \pm 0.93$ \\
\hline 0.1 & $0.40^{\mathrm{b}} \pm 0.37$ & $0.67^{b} \pm 0.63$ & & $1.07^{b} \pm 0.61$ & $0.32^{c} \pm 0.31$ & $1.39^{\mathrm{b}} \pm 0.91$ \\
\hline 0.2 & $0.57^{\mathrm{ab}} \pm 0.81$ & $1.38^{\mathrm{ab}} \pm 1.01$ & & $2.94^{\mathrm{ab}} \pm 1.21$ & $7.72^{b c} \pm 2.69$ & $9.66^{\mathrm{b}} \pm 3.43$ \\
\hline 0.4 & $0.67^{\mathrm{ab}} \pm 0.09$ & $5.15^{\mathrm{a}} \pm 0.61$ & & $5.82^{\mathrm{ab}} \pm 1.70$ & $1.97^{c} \pm 0.63$ & $7.79^{\mathrm{b}} \pm 0.07$ \\
\hline 0.6 & $2.11^{\mathrm{ab}} \pm 1.37$ & $4.22^{\mathrm{ab}} \pm 1.92$ & & $6.33^{\mathrm{ab}} \pm 2.83$ & $61.65^{\mathrm{a}} \pm 33.81$ & $67.98^{\mathrm{a}} \pm 31.04$ \\
\hline 0.8 & $3.21^{\mathrm{a}} \pm 1.80$ & $5.18^{\mathrm{a}} \pm 2.32$ & & $8.38^{\mathrm{a}} \pm 3.96$ & $47.31^{\mathrm{ab}} \pm 12.10$ & $55.69^{\mathrm{a}} \pm 8.87$ \\
\hline \multicolumn{7}{|l|}{ P. ostreatus $\mathrm{H} 195$} \\
\hline Control & $0.42^{\mathrm{d}} \pm 0.19$ & $0.16^{\mathrm{c}} \pm 0.02$ & \multirow[t]{6}{*}{$<0.10$} & $0.59^{\mathrm{e}} \pm 0.20$ & $1.16^{\mathrm{b}} \pm 0.05$ & $1.74^{\mathrm{d}} \pm 0.16$ \\
\hline 0.1 & $12.81^{\mathrm{c}} \pm 2.43$ & $2.35^{\mathrm{c}} \pm 0.49$ & & $15.16^{\mathrm{d}} \pm 1.99$ & $8.31^{\mathrm{a}} \pm 3.99$ & $23.47^{c} \pm 3.06$ \\
\hline 0.2 & $30.49^{\mathrm{a}} \pm 5.30$ & $<0.10^{\mathrm{c}}$ & & $30.49^{\mathrm{ab}} \pm 5.30$ & $2.17^{b} \pm 1.31$ & $32.66^{\mathrm{ab}} \pm 4.32$ \\
\hline 0.4 & $22.53^{b} \pm 2.77$ & $<0.10^{\mathrm{c}}$ & & $22.53^{\mathrm{cd}} \pm 2.77$ & $3.64^{\mathrm{ab}} \pm 1.39$ & $26.18^{\mathrm{abc}} \pm 3.87$ \\
\hline 0.6 & $13.23^{\mathrm{c}} \pm 0.93$ & $9.88^{b} \pm 2.05$ & & $23.11^{b c} \pm 2.29$ & $1.98^{\mathrm{b}} \pm 0.70$ & $25.09^{\mathrm{bc}} \pm 2.02$ \\
\hline 0.8 & $11.89^{c} \pm 0.34$ & $19.55^{\mathrm{a}} \pm 2.25$ & & $31.44^{\mathrm{a}} \pm 1.91$ & $3.04^{b} \pm 1.11$ & $34.48^{\mathrm{a}} \pm 3.01$ \\
\hline \multicolumn{7}{|l|}{ P. ostreatus HK35 } \\
\hline Control & $0.19^{c} \pm 0.16$ & $0.03^{\mathrm{a}} \pm 0.02$ & \multirow[t]{3}{*}{$<0.10$} & $0.22^{\mathrm{c}} \pm 0.17$ & $0.39^{b} \pm 0.59$ & $0.61^{\mathrm{b}} \pm 0.55$ \\
\hline 0.1 & $18.29^{\mathrm{b}} \pm 4.79$ & $<0.10^{\mathrm{b}}$ & & $18.29^{\mathrm{b}} \pm 4.79$ & $2.63^{b} \pm 1.35$ & $20.92^{b} \pm 6.09$ \\
\hline 0.2 & $29.89^{\mathrm{a}} \pm 3.55$ & $<0.10^{\mathrm{b}}$ & & $29.89^{\mathrm{a}} \pm 3.55$ & $38.89^{\mathrm{a}} \pm 22.18$ & $68.78^{a} \pm 19.04$ \\
\hline
\end{tabular}

a, b, c, d Mean values $(n=3) \pm$ standard deviations; identical superscripts denote no significant $(p<0.05)$ difference between mean values in column according to Tukey's HDS test (MANOVA)

Table 2 Effect of the different concentrations of As species on biomass ( $\mathrm{g}$ ) of the fungus

\begin{tabular}{llllcl}
\hline As species addition & A. bisporus & H. erinaceus & P. eryngii & P. ostreatus $($ H195) & P. ostreatus $($ HK35) \\
\hline Control & $378.49^{\mathrm{a}} \pm 14.57$ & $43.46^{\mathrm{a}} \pm 5.83$ & $71.45^{\mathrm{a}} \pm 1.49$ & $202.21^{\mathrm{a}} \pm 30.26$ & $304.20^{\mathrm{a}} \pm 20.84$ \\
0.1 & $368.21^{\mathrm{a}} \pm 30.75$ & $42.71^{\mathrm{a}} \pm 5.52$ & $69.96^{\mathrm{a}} \pm 2.49$ & $196.31^{\mathrm{a}} \pm 36.78$ & $244.53^{\mathrm{b}} \pm 24.86$ \\
0.2 & $347.02^{\mathrm{a}} \pm 23.74$ & $38.75^{\mathrm{a}} \pm 5.51$ & $67.96^{\mathrm{a}} \pm 1.90$ & $171.02^{\mathrm{a}} \pm 4.54$ & $190.23^{\mathrm{b}} \pm 71.23$ \\
0.4 & $341.24^{\mathrm{a}} \pm 13.16$ & $39.08^{\mathrm{a}} \pm 3.59$ & $71.27^{\mathrm{a}} \pm 3.30$ & $152.21^{\mathrm{ab}} \pm 19.03$ & $\mathrm{nf}$ \\
0.5 & $344.76^{\mathrm{a}} \pm 9.09$ & $41.73^{\mathrm{a}} \pm 2.06$ & $72.37^{\mathrm{a}} \pm 1.54$ & $77.18^{\mathrm{bc}} \pm 33.13$ & $\mathrm{nf}$ \\
0.8 & $354.86^{\mathrm{a}} \pm 22.40$ & $38.08^{\mathrm{a}} \pm 3.50$ & $67.98^{\mathrm{a}} \pm 5.31$ & $46.16^{\mathrm{c}} \pm 24.38$ & $\mathrm{nf}$ \\
\hline
\end{tabular}

\section{$n f$ no fungi}

a, b, c Mean values $(n=3) \pm$ standard deviations; identical superscripts denote no significant $(p<0.05)$ difference between mean values in column according to Tukey's HDS test (MANOVA) 
Fig. 1 Characteristics of $P$. ostreatus a (H195) fruiting bodies growing on substrate with diverse As salts added, $\mathbf{b}$ (HK35) fruiting bodies growing on substrate with diverse As salts added (a)

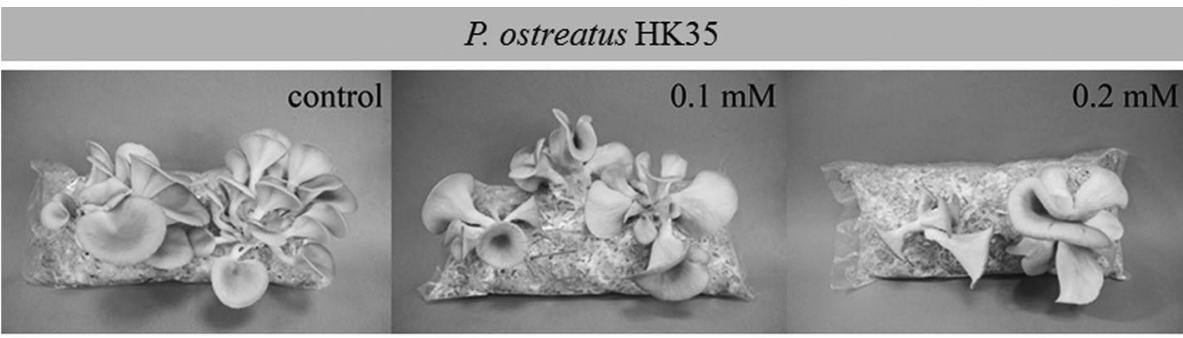

(b) P. ostreatus $\mathrm{H} 195$

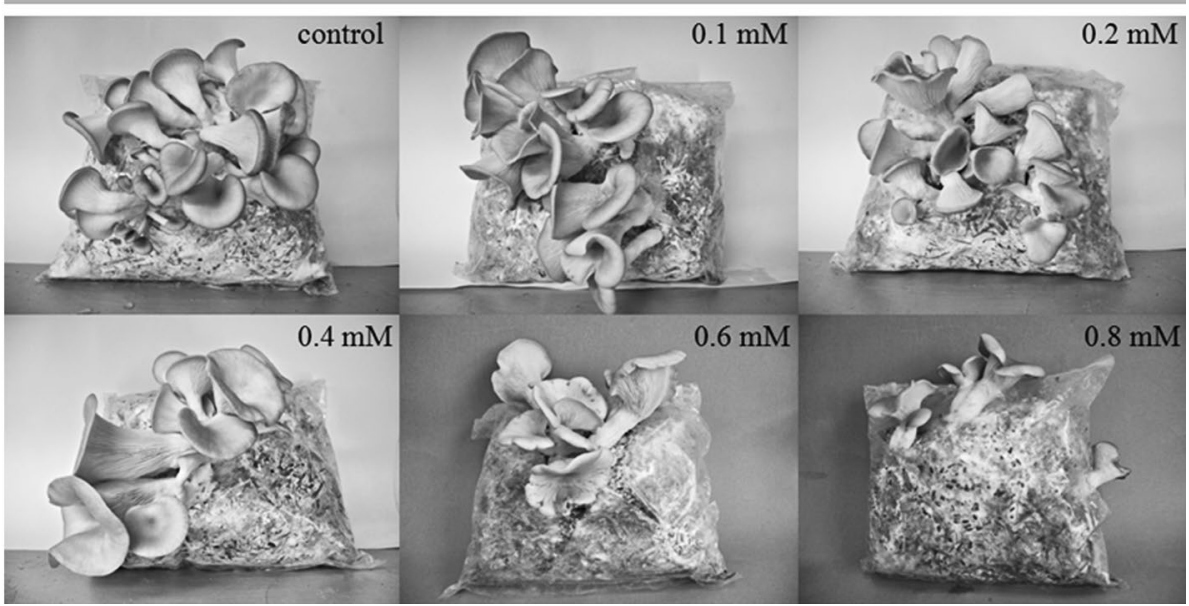

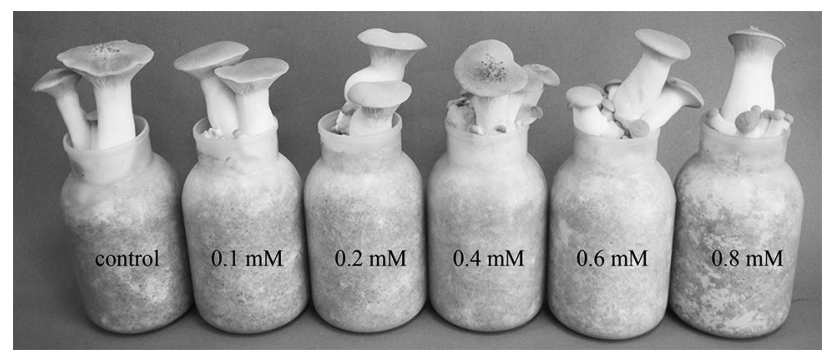

Fig. 2 Characteristics of $P$. eryngii fruiting bodies growing on substrate with diverse As salts added

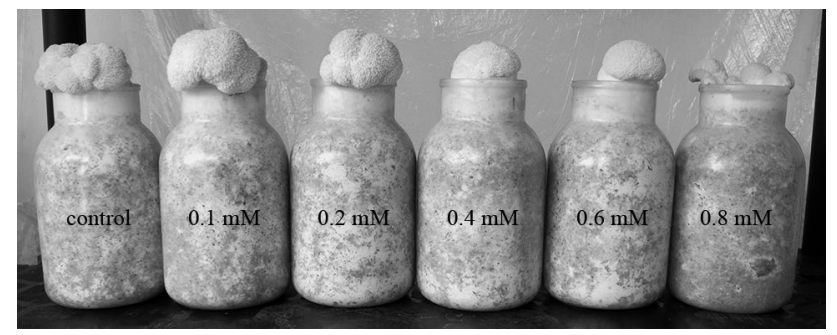

Fig. 3 Characteristics of $H$. erinaceus fruiting bodies growing on substrate with diverse As salts added

and DMAA. In our study, the mushrooms were simultaneously exposed to three different As forms to show which one accumulates preferably. The greatest increase was found for $\mathrm{As}(\mathrm{V})$ and

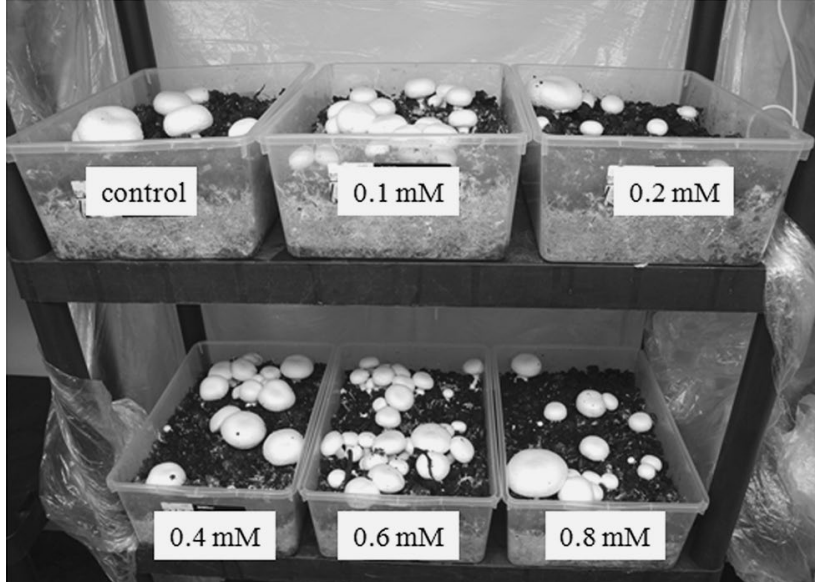

Fig. 4 Characteristics of A. bisporus fruiting bodies growing on substrate with diverse As salts added

the lowest for DMAA. Compared to other studied mushroom species, the levels of $\mathrm{As}(\mathrm{V})$ were very low, while the organic As content did not increase. This indicates that $A$. bisporus is potentially able to take up only certain forms of As, effectively excluding others - the mechanism which is likely behind its high tolerance rather than biotransformation of inorganic forms to less toxic organic As compounds. The comparison of total As content in edible mushrooms available through retail sale in Brazil also demonstrates that $A$. bisporus contains levels which can be considered as safe [20]. Along with our experimental 
observations, it can be concluded that this species does not fall into the 'group of special care' regarding the issue of As contamination. This may, however, not apply to other members of the genus Agaricus able to accumulate As from natural substrates to remarkable levels above $10 \mathrm{mg} \mathrm{kg}^{-1} \mathrm{DW}[17,30]$. One should, however, consider that wild edible mushrooms are potentially subject to a higher contamination level than cultivated species, for which the environmental conditions can be controlled.

According to our knowledge, the present study is the first report on kinetics of As uptake and accumulation by H. erinaceus, an edible mushroom species revealing therapeutic properties [31]. Importantly, the increase in total As content was observed only when cultivation was maintained at an initial metalloid concentration of over $0.2 \mathrm{mM}$. When the substrate was treated with high As levels, H. erinaceus had a general tendency to accumulate the inorganic form. The highest reported concentration of inorganic As exceeded $7.0 \mathrm{mg} \mathrm{kg}^{-1} \mathrm{DW}$, and despite slightly decreased biomass, the mushroom maintained its growth. If one considers the withdrawn PTWI which was set at $15 \mu \mathrm{g}$ of As per body weight, the consumption of $100 \mathrm{~g}$ of such a food product by a person of $60 \mathrm{~kg}$ would represent over $77 \%$ of PTWI delivered only by inorganic metalloid species. Therefore, it is crucial to control As content in substrates used for cultivation to produce safe food, especially for products of potential medical use.

Species of the Pleurotus genus have been demonstrated to synthesize lectins mitigating the As-induced oxidative stress in mammals [32]. However, fruiting bodies of these mushrooms may have such (and any other) biopharmaceutical use only if their biomass is not contaminated with As. The present study clearly demonstrates that from the tested species, P. eryngii and $P$. ostreatus possess the highest ability to accumulate As available in the substrate. The former accumulated As mostly in the organic form despite the total inorganic content, mainly in the form of $\mathrm{As}(\mathrm{V})$, increased with the substrate As concentration and exceeded $8.0 \mathrm{mg} \mathrm{kg}^{-1} \mathrm{DW}$ for the highest assayed metalloid level. Increase in $\mathrm{As}(\mathrm{V})$ uptake was likely a cause of lower biomass production. The greatest retardation of growth (or its complete cessation) was, however, observed for $P$. ostreatus. Both strains accumulated very high inorganic As content, up to $30 \mathrm{mg} \mathrm{kg}^{-1} \mathrm{DW}$, which in the case of a $60-\mathrm{kg}$ weight person would represent over $330 \%$ of PTWI if $100 \mathrm{~g}$ of fruiting bodies were consumed. Importantly, the inorganic As content was largely increased in both strains even after as little as $0.1 \mathrm{mM}$ of each studied form was added to the substrate, indicating a high ability of $P$. ostreatus to bioconcentrate As from the ambient environment. It was, however, reported that cultivated $P$. ostreatus and P. eryngii contain significantly lower As levels, but none of these investigations described the chemical characteristics of the substrate [20,33]. These mushroom species, particularly $P$. ostreatus, can therefore be considered as those requiring 'special care', where the purity of the substrate is essential for production of a safe food product.
Quality of a cultivated species requires control of the cultivation substrate. For example, wheat, often used as a substrate, may accumulate high As contents when growing at As-contaminated sites [24, 34, 35], so it is crucial to grow wheat on soils with no significant As levels to exclude the possibility of further As biotransfer and risk of human exposures to relevant concentrations of As.

\section{Conclusions}

The present study demonstrates the importance of substrate quality in production of safe fungi for human food. As found, interspecific differences in As uptake and form of the metalloid accumulated in fungal tissue were observed. Generally, inorganic As considered as the most threatening to human health, decreased in the following order: $P$. ostreatus $>P$. eryngii $>H$. erinaceus $>A$. bisporus. The greater the inorganic levels of As were taken up and accumulated, the more significant growth retardation and decrease in fruiting biomass were the observed.

Acknowledgments The authors gratefully acknowledge the financial support by the Poznan University of Life Sciences research project "Biologically active organic compounds-synthesis, properties and analysis" (\# 508.472.00), Faculty of Wood Technology, Poznań University of Life Sciences.

\section{Compliance with ethical standards}

Conflict of interest None.

Compliance with Ethics Requirements This article does not contain any studies with human or animal subjects.

Open Access This article is distributed under the terms of the Creative Commons Attribution 4.0 International License (http://creativecommons.org/licenses/by/4.0/), which permits unrestricted use, distribution, and reproduction in any medium, provided you give appropriate credit to the original author(s) and the source, provide a link to the Creative Commons license, and indicate if changes were made.

\section{References}

1. Turpeinen R, Pantsar-Kallio M, Haggblom M, Kairesalo $T$ (1999) Influence of microbes on the mobilization, toxicity and biomethylation of arsenic in soil. Sci Total Environ 236:173-180

2. Schlebusch CM, Gattepaille LM, Engström K, Vahter M, Jakobsson M, Broberg K (2015) Human adaptation to arsenic-rich environments. Mol Biol Evol. doi:10.1093/molbev/msv046

3. JECFA (1988). 658. Arsenic. WHO Food Additive Series 24

4. FAO and WHO (2011) Safety evaluation of certain contaminants in food. WHO Food Additive Series 63/FAO JECFA Monographs 8. WHO Press, Geneva

5. Agency for Toxic Substances and Disease Registry (ATSDR) (2007) Toxicological profile for Arsenic. U.S. Department of Health and Human Services, Public Health Service, Atlanta 
6. Chappell WR, Beck BD, Brown KG, Chaney R, Cothern R, Cothern CR, Irgolic KJ, North DW, Thornton I, Tsongas TA (1997) Inorganic arsenic: a need and an opportunity to improve risk assessment. Environ Health Perspect 105:1060-1067

7. Schoof RA, Yost LJ, Eickhoff J, Crecelius EA, Cragin DW, Meacher DM, Menzel DB (1999) A market basket survey of inorganic arsenic in food. Food Chem Toxicol 37:839-846

8. Hedegaard R, Vingborg S (2013) Total and inorganic arsenic in dietary supplements based on herbs, other botanicals and algae-a possible contributor to inorganic arsenic exposure. Anal Bioanal Chem 405:4429-4435

9. Llorente-Mirandes T, Calderón J, Centrich F, Rubio R, LópezSánchez JF (2014) A need for determination of arsenic species at low levels in cereal-based food and infant cereals. Validation of a method by IC-ICPMS. Food Chem 147:377-385

10. Sofuoglu SC, Güzelkaya H, Akgül Ö, Kavcar P, Kurucaovalı F, Sofuoglu A (2014) Speciated arsenic concentrations, exposure, and associated health risks for rice and bulgur. Food Chem Toxicol 64:184-191

11. Rzymski P, Niedzielski P, Kaczmarek N, Jurczak T, Klimaszyk $P$ (2015) The multidisciplinary approach to safety and toxicity assessment of microalgae-based food supplements following clinical cases of poisoning. Harmful Algae 46:34-42

12. Melgar MJ, Alonso J, García MA (2014) Total contents of arsenic and associated health risks in edible mushrooms, mushroom supplements and growth substrates from Galicia (NW Spain). Food Chem Toxicol 73C:44-50

13. Chittaragi A, Naika R (2014) Determination of trace elements on some wild mushroom samples encountered from Western ghats of Karnataka. J Chem Pharmacol Res 6:2124-2135

14. Elekes CC, Busuioc G (2010) Heavy metals bioaccumulation in species of wild growing mushrooms. Lucrări Ştiinţifice - seria Agronomie 53:86-91

15. Mleczek M, Siwulski M, Mikołajczak P, Gąsecka M, Sobieralski K, Szymańczyk M, Goliński P (2015) Content of selected elements in Boletus badius fruiting bodies growing in extremely polluted wastes. J Environ Sci Heal A 50:767-775

16. Niedzielski P, Mleczek M, Siwulski M, Rzymski P, Gąsecka M, Kozak L (2015) Supplementation of cultivated mushroom species with selenium: bioaccumulation and speciation study. Eur Food Res Technol 241:419-426

17. Vetter J (2004) Arsenic content of some edible mushroom species. Eur Food Res Technol 219:71-74

18. Larsen EH, Hansen M, Gössler W (1998) Speciation and health risk considerations of arsenic in the edible mushroom Laccaria amethystina collected from contaminated and uncontaminated locations. Appl Organomet Chem 12:285-291

19. Svoboda L, Chrastny V (2007) Contents of eight trace elements in edible mushrooms from a rural area. Food Addit Contam 25:51-58

20. Maihara VA, Moura PL, Catharino MG, Castro LP, Figueira RCL (2008) Arsenic and cadmium content in edible mushrooms from São Paulo, Brazil determined by INAA and GF AAS. J Radioanal Nucl Ch 278:395-397

21. Heitkemper DT, Vela NP, Stewart KR, Westphal CS (2001) Determination of total and speciated arsenic in rice by ion chromatography and inductively coupled plasma mass spectrometry. J Anal Atom Spectrom 16:299-306

22. Madejón P (2003a) Elementos traza y nutrientes en álamo blanco tras el vertido tóxico de las minas de Aznalcóllar Invest Agrar: Sist Recur For 12:19-32

23. Madejón P, Marañón T, Murillo JM, Cabrera F (2003b) Evolution of arsenic, lead, iron and manganese in evergreen trees affected by the Aznalcóllar mine spill. In: Del Valls TA, Blasco $\mathrm{J}$ (eds) Integrated assessment and management of the ecosystems affected by the Aznalcóllar mining spill (Sw, Spein). UNESCO Publication, Puerto Real

24. Demirbaş A (2005) Heavy metal contents of fly ashes from selected biomass samples. Energy Source 27:1269-1276

25. Niedzielski P, Mleczek M, Magdziak Z, Siwulski M, Kozak L (2013) Selected arsenic species: As(III), As(V) and dimethylarsenic acid (DMAA) in Xerocomus badius fruiting bodies. Food Chem 141:3571-3577

26. Gonzalvez A, Llorens A, Cervera ML, Armenta S, de la Guardia M (2009) Non-chromatographic speciation of inorganic arsenic in mushrooms by hydride generation atomic fluorescence spectrometry. Food Chem 115:360-364

27. Burguera JL, Burguera M, Rivas C, Carrero P (1998) On-line cryogenic trapping with microwave heating for the determination and speciation of arsenic by flow injection/hydride generation/ atomic absorption spectrometry. Talanta 45:531-542

28. Chatterjee A, Das D, Mandal BK, Chowdhury TR, Samanta G, Chakrabort D (1995) Arsenic in ground water in six districts of West Bengal, India: the biggest arsenic calamity in the world part 1 . Arsenic species in drinking water and urine of the affected people. Analyst 120:643-650

29. Soeroes C, Kienzl N, Opoli I, Dernovics M, Fodor P, Kuehnelt D (2005) Arsenic uptake and arsenic compounds in cultivated Agaricus bisporus. Food Control 16:459-464

30. Pelkonen R, Alfthan G, Järvinen O (2006) Cadmium, lead, arsenic and nickel in wild edible mushrooms. The Finnish Environment, Edita Print Oy

31. Khan MA, Tania M, Liu R, Rahman MM (2013) Hericium erinaceus: an edible mushroom with medicinal values. J Complement Integr Med. doi:10.1515/jcim-2013-0001

32. Bera AK, Rana T, Das S, Bhattacharya D, Pan D, Bandyopadhyay S, Das SK (2011) Mitigation of arsenic-mediated renal oxidative stress in rat by Pleurotus florida lectin. Hum Exp Toxicol 30:940-951

33. Alam N, Amin R, Khan A, Ara I, Shim MJ, Lee MW, Lee TS (2008) Nutritional analysis of cultivated mushrooms in Bangladesh-Pleurotus ostreatus, Pleurotus sajor-caju, Pleurotus florida and Calocybe indica. Mycobiology 36:228-232

34. Zhang WD, Liu DS, Tian JC, He FL (2009) Toxicity and accumulation of arsenic in wheat (Triticum aestivum L.) varieties of China. ФYTON 78:147-154

35. Liu QJ, Zheng CM, Hu CX, Tan QL, Sun XC, Su JJ (2012) Effects of high concentrations of soil arsenic on the growth of winter wheat (Triticum aestivum $\mathrm{L}$ ) and rape (Brassica napus). Plant Soil Environ 58:22-27 